\title{
Effect of Saline Water Application through Different Irrigation Intervals on Tomato Yield and Soil Properties
}

\author{
Mahmoud Rahil $^{{ }^{*}}$, Hajaj Hajjeh ${ }^{1}$, Alia Qanadillo ${ }^{2}$ \\ ${ }^{1}$ Faculty of Agricultural Science and Technology, Palestine Technical University-Kadoorie, Tulkarm, Palestine; ${ }^{2}$ Palestinian National \\ Agriculture Research Center, Jenin, Palestine. \\ Email: ${ }^{*}$ mrahail@yahoo.com
}

Received April 29 $9^{\text {th }}, 2013$; revised June $2^{\text {nd }}, 2013$; accepted June $9^{\text {th }}, 2013$

Copyright (C) 2013 Mahmoud Rahil et al. This is an open access article distributed under the Creative Commons Attribution License, which permits unrestricted use, distribution, and reproduction in any medium, provided the original work is properly cited.

\begin{abstract}
A field study was conducted on the experimental farm of ministry of agriculture, located at Palestine Technical University-Kadoorie, to investigate the effects of saline water irrigation through three irrigation intervals on yield of tomato crop and soil properties. The land was prepared and divided into 12 treatments, each of 48 square meters on the first of April. Tomato seedlings were planted on 25 April 2010; the seedlings were irrigated with fresh water for a period of 10 days after planting. Three levels of saline water irrigation $(3,5,7 \mathrm{dS} / \mathrm{m})$ plus fresh water as control were applied during the growing season. The four irrigation water treatments were applied through three irrigation intervals (every day, every second day and every three days). Gravimetric soil moisture content and soil electrical conductivity were monitored every two weeks during the growing period. Yield measurements were taken for total fruit yield, marketable yield as a percent of total yield, and average fruit weight of each treatment. Results of this study indicated that, plant treatments irrigated with saline water gave the highest yield for treatments irrigated every day compared to the treatments irrigated every second day and every three days. Statistical analysis showed significant differences in yield reduction between every second day and every three days irrigation intervals under 5 and $7 \mathrm{dS} / \mathrm{m}$ saline irrigation levels, while there was no significant difference between irrigation intervals under $3 \mathrm{dS} / \mathrm{m}$ salinity level.
\end{abstract}

Keywords: Saline Water; Irrigation Interval; Soil; Tomato; Electrical Conductivity

\section{Introduction}

The declining availability of fresh water has become a worldwide problem, which endorses the development of alternative, secondary quality water resources for agricultural use. In Palestine, besides water scarcity, water quality is deteriorating and water salinity is increasing due to uncontrolled discharges of untreated or poorly treated wastewater, over-abstraction of the aquifers, and the excessive use of fertilizers in agriculture. Field drainage water, urban wastewater, domestic gray water and saline water are reused and recycled for irrigation in many parts of the world. When saline water is used, several factors have to be considered: plant tolerance, irrigation system, water management strategies, irrigation intervals and soil properties.

Salinity can negatively affect plants through three major components: osmotic, nutritious, and toxic stresses $[1,2]$. When exposed to salinity, growth, development,

\footnotetext{
"Corresponding author.
}

and yield of most cultivated crops tend to decline, with consequent reduction in their economic value [3]. However, the response pattern of many crop species may substantially change due to environmental conditions (e.g., soil properties and weather) as well as by agricultural practices [4] (e.g., irrigation methods). Many studies have reported substantial increases in crop yield as a result of suitable irrigation management under saline conditions [3,5-9].

Several studies have indicated that when saline water is used for irrigation, more attention should be given to minimize root-zone salinity [10-12]. Others have indicated the need to select appropriate irrigation systems and practices that will supply a sufficient quantity of water to the root zone to meet the evaporative demand and to minimize salt accumulation inside the root zone [13]. Other approach is to select crops and varieties that can tolerate a degree of water and salinity stress $[14,15]$.

The objective of this work is to study the effects of irrigation with three levels of saline water $(3,5,7 \mathrm{dS} / \mathrm{m})$ 
and with fresh water as control, through three irrigation intervals (every day, every second day, and every three days) using drip irrigation system on growth and yield of tomato crop and on soil salinity.

\section{Materials and Methods}

A field study was conducted in the experimental farm of the ministry of agriculture, located at Palestine Technical University-Kadoorie, to investigate the effect of irrigation with three saline water levels through three irrigation intervals on growth and yield of tomato crop and soil salinity. To conduct this study, the experimental field was prepared and divided into 12 treatments, each of 48 square meters, at the beginning of April 2010. Basic fertilizers at rate of $200 \mathrm{~kg} / \mathrm{du}$ superphosphate and 150 $\mathrm{kg} / \mathrm{du}$ ammoniac were applied before planting. A drip irrigation system was installed and characterized by emitter discharge of $4 \mathrm{l} / \mathrm{hr}$ and spacing between emitters and laterals at 40 and $100 \mathrm{~cm}$, respectively.

Tomato seedlings were cultivated in an open field, on 25 April 2010. An amount of $101 \mathrm{~kg} / \mathrm{du}$ compound fertilizer (20-8-11), and $28 \mathrm{~kg} / \mathrm{du}$ compound fertilizer (14-14-14) were applied during the growing period.

Plants were irrigated with three saline water levels (3, $5,7 \mathrm{dS} / \mathrm{m}$ ) and with fresh water as control. Irrigation water treatments were applied through three irrigation intervals (every day, every second day and every three days) with a total of 12 treatments. Saline water was prepared by mixing fresh water with sodium chloride salt in three tanks. Same amount of irrigation water were applied for each treatment during the growing period (Figure 1). At the beginning of the growing period, all treatments were irrigated with fresh water for a period of 10 days.

Soil samples were taken at initial condition at depths of $0-20,20-40 \& 40-60 \mathrm{~cm}$, and every two weeks during the experimental period at depth of $0-30 \mathrm{~cm}$. Soil samples were analyzed at a central laboratory in Nablus to study the (soil texture, soil moisture content, soil electrical conductivity, soil $\mathrm{pH}, \mathrm{Ca}, \mathrm{Mg}$, and $\mathrm{Na}$ ). Soil electrical conductivity was analyzed using saturation past.

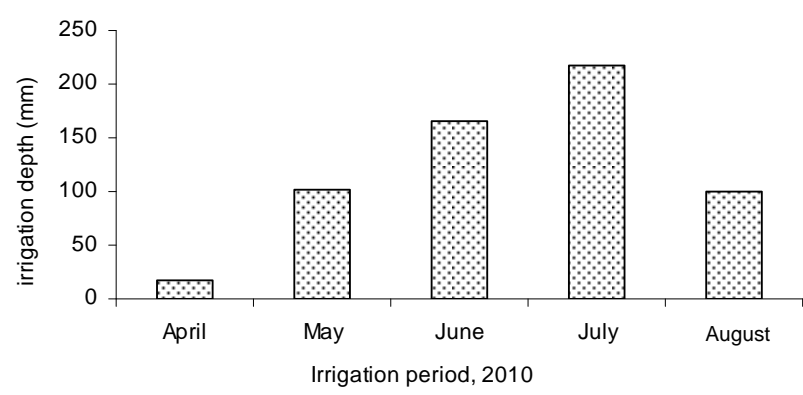

Figure 1. The monthly amount of irrigation water that applied for each treatment during the growing period.
(Table 1) shows the physical and chemical properties of the soil at initial condition. Plant measurements were taken for total yield, marketable yield, and average fruit weight of each treatment.

\section{Results and Discussion}

\subsection{Yield Production of Tomato}

The results of this study showed that, the treatments irrigated with fresh water (control) gave the highest yield compared to the treatments irrigated with different saline water levels, particularly for plants irrigated every second day. Under saline irrigation, the highest yield observed for treatments irrigated every day compared to the treatments irrigated every second day and every three days (Figure 2). Reduced total and marketable fruit yield with increasing salinity level was a consequence of reduction in fruit fresh weight (Table 2). [16-18] reported

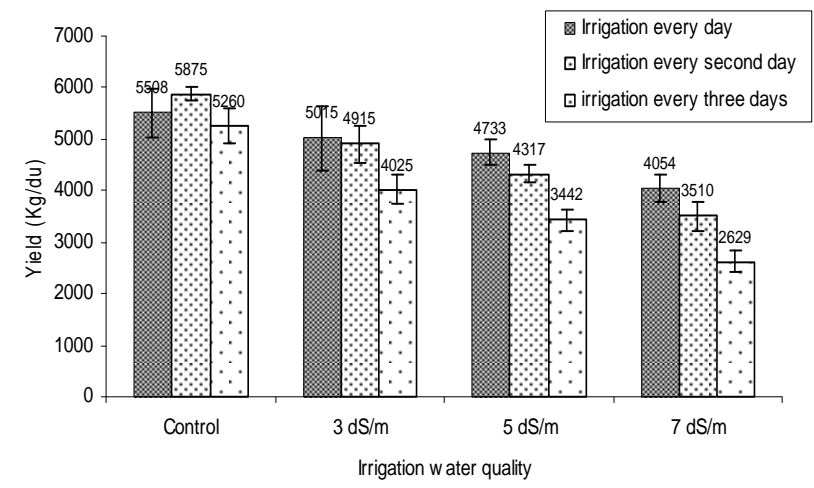

Figure 2. Impact of three levels of saline water irrigation through three irrigation intervals on tomato yield.

Table 1. The physio-chemical properties of the soil.

\begin{tabular}{lccccccccc}
\hline $\begin{array}{l}\text { Depth } \\
\text { (cm) }\end{array}$ & Texture & $\begin{array}{c}\mathrm{EC}_{\mathrm{e}} \\
(\mathrm{dS} / \mathrm{m})\end{array}$ & $\mathrm{pH}$ & $\begin{array}{c}\mathrm{TDS} \\
\mathrm{ppm}\end{array}$ & $\begin{array}{l}\mathrm{Ca}^{2+} \\
\mathrm{ppm}\end{array}$ & $\begin{array}{c}\mathrm{Mg}^{2+} \\
\mathrm{ppm}\end{array}$ & $\begin{array}{l}\mathrm{Na}^{1+} \\
\mathrm{ppm}\end{array}$ & $\begin{array}{c}\mathrm{K}^{1+} \\
\mathrm{ppm}\end{array}$ & $\begin{array}{c}\mathrm{Cl}^{1-} \\
\mathrm{ppm}\end{array}$ \\
\hline 0 - 20 Sandy clay & 0.28 & 7.3 & 181.3 & 3.7 & 4.7 & 22.5 & 3.3 & 132.9 \\
20 - 40 Sandy clay & 0.27 & 7.3 & 171.5 & 3.6 & 5.1 & 23.4 & 3.1 & 138.4 \\
40 - 60 Sandy clay & 0.25 & 7.3 & 161.6 & 3.4 & 4.7 & 22.5 & 2.9 & 141.2 \\
\hline
\end{tabular}

Table 2. The average fruit weight of tomato under saline water irrigation through three irrigation intervals.

\begin{tabular}{cccc}
\hline \multirow{2}{*}{$\begin{array}{c}\text { Irrigation } \\
\text { salinity } \\
\text { level }\end{array}$} & Every day & Every second day & Every three days \\
\cline { 2 - 4 } & Fruit weight $(\mathrm{g})$ & Fruit weight $(\mathrm{g})$ & Fruit weight $(\mathrm{g})$ \\
\hline Control & 133 & 134 & 130 \\
$3 \mathrm{dS} / \mathrm{m}$ & 130 & 122 & 120 \\
$5 \mathrm{dS} / \mathrm{m}$ & 126 & 115 & 113 \\
$7 \mathrm{dS} / \mathrm{m}$ & 102 & 97 & 92 \\
\hline
\end{tabular}


that, the numbers of fruits was not affected by moderate salinity, and the yield reduction was entirely due to smaller fruit. Others found that, the number of harvested fruit per plant reduced with salinity [19-21].

\subsection{Relative Yield Reduction}

Total and marketable fruit yield decreased with increasing salinity level, and clearly followed Maas and Hoffman model [22], particularly in treatments irrigated every three days. Moreover, there were differences in yield reduction through the three irrigation intervals. Tomato yield reduced $9 \%$ under $3 \mathrm{dS} / \mathrm{m}$ saline irrigation level when plants irrigated every day, compared to the yield reduction of $16 \%$ and $23 \%$, through every second day and every three days irrigation intervals, respectively, under the same salinity level. Under $5 \mathrm{dS} / \mathrm{m}$ salinity level the yield reduced $14 \%$, when plants irrigated every day, while the yield reduced $27 \%$ and $35 \%$, for treatments irrigated every second day and every three days, respectively, under the same salinity level. In addition to that, total yield reduced only $26 \%$, under $7 \mathrm{dS} / \mathrm{m}$ salinity level when plants irrigated every day, compared to yield reduction of $40 \%$ and $50 \%$ for treatments irrigated every second day and every three days, respectively (Table 3 ). Statistically, there were no significant differences in yield reduction between irrigation intervals under $3 \mathrm{dS} / \mathrm{m}$ saline irrigation level. In contrast, under 5 and $7 \mathrm{dS} / \mathrm{m}$ saline irrigation, statistical analysis showed significant differences in yield reduction between every day and every three days irrigation intervals (Figure 3). These results indicated that, when using highly saline water for irrigation purposes, short irrigation interval (every day) is recommended to decrease the yield reduction caused by salinity stress.

\subsection{Soil Moisture Content}

The soil moisture content status depended on the irrigation intervals and salinity levels of irrigation water. Irrespective of the irrigation intervals, the gravimetric soil moisture content $\left(\theta_{w}\right)$ of the treatments irrigated with fresh water (control) was lower than that under different levels of saline water irrigation (Figure 4). This explains the potential of plant to uptake much water under fresh

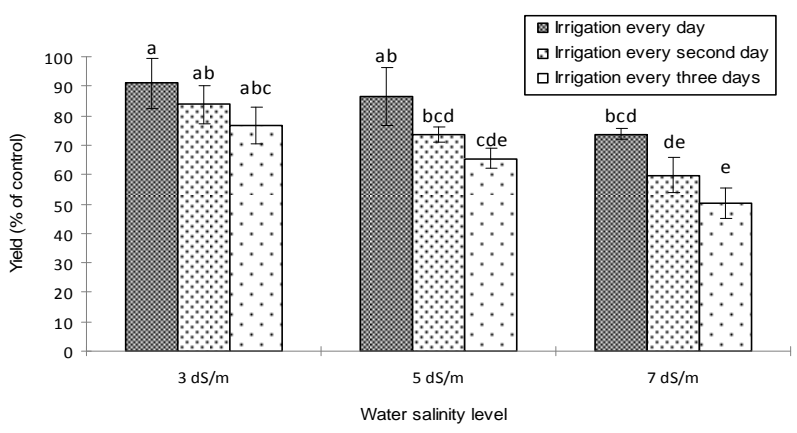

Figure 3. Impact of saline water irrigation levels through three irrigation intervals on tomato yield reduction. Treatments with the same letters do not differ significantly $(\mathrm{P}<$ 0.05).
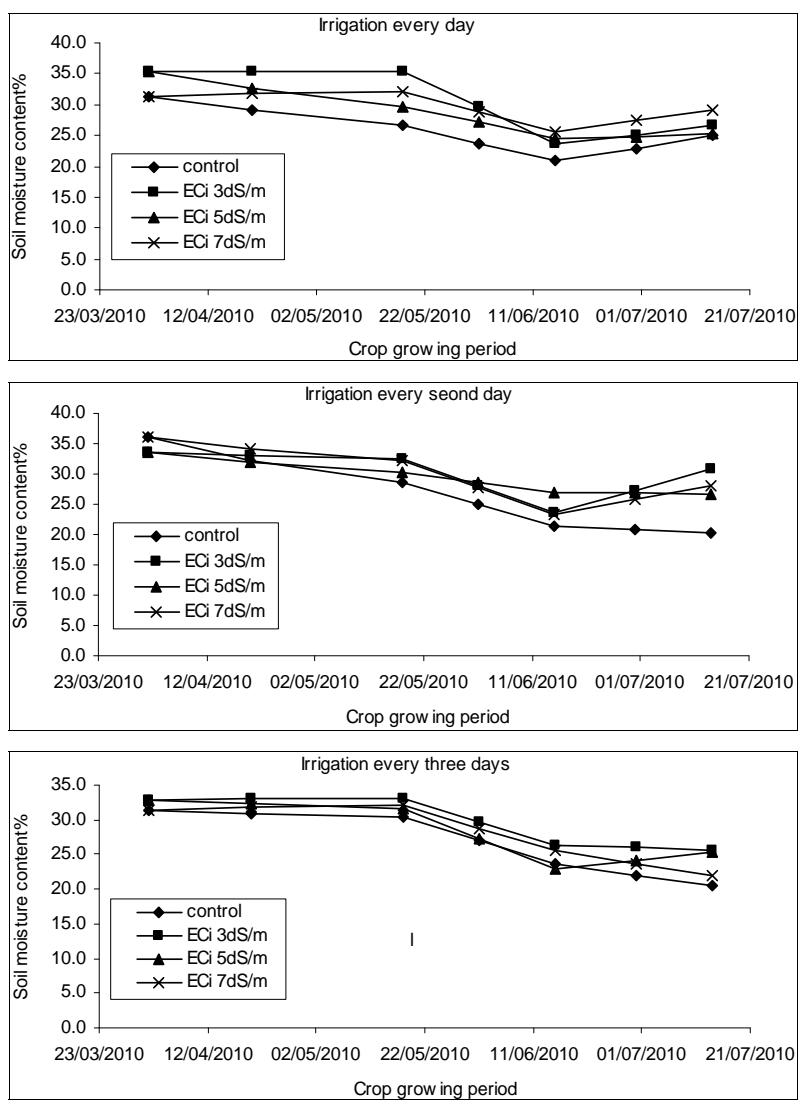

Figure 4. Impact of saline water irrigation through three irrigation intervals on soil moisture content during the growing period at depth of $0-30 \mathrm{~cm}$.

Table 3. Total yield of tomato and percent of yield reduction under saline water irrigation through three irrigation intervals.

\begin{tabular}{|c|c|c|c|c|c|c|}
\hline \multirow{3}{*}{$\begin{array}{c}\text { Irrigation } \\
\text { salinity } \\
\text { level }\end{array}$} & \multicolumn{6}{|c|}{ Irrigation intervals } \\
\hline & \multicolumn{2}{|c|}{ Every day } & \multicolumn{2}{|c|}{ Every second day } & \multicolumn{2}{|c|}{ Every three days } \\
\hline & Total yield $(\mathrm{Kg} / \mathrm{du})$ & Yield reduction $(\%)$ & Total yield $(\mathrm{Kg} / \mathrm{du})$ & Yield reduction $(\%)$ & Total yield $(\mathrm{Kg} / \mathrm{du})$ & Yield reduction $(\%)$ \\
\hline $3 \mathrm{dS} / \mathrm{m}$ & $5015 \pm 605$ & 9 & $4915 \pm 356$ & 16 & $4025 \pm 278$ & 23 \\
\hline $5 \mathrm{dS} / \mathrm{m}$ & $4733 \pm 247$ & 14 & $4317 \pm 168$ & 27 & $3442 \pm 207$ & 35 \\
\hline $7 \mathrm{dS} / \mathrm{m}$ & $4054 \pm 260$ & 26 & $3510 \pm 286$ & 40 & $2629 \pm 203$ & 50 \\
\hline
\end{tabular}


water irrigation without water stress. $[23,24]$ found that, tomato plants irrigated with saline water transpire less water than when fresh water is used. [25] indicated that, irrespective of irrigation interval, the volumetric soil moisture under saline water treatment was higher than that under good quality water treatments.

\subsection{Soil Electrical Conductivity and $\mathrm{pH}$}

The results of soil analysis before planting showed that the initial electrical conductivity of the soil was 0.28 $\mathrm{dS} / \mathrm{m}$, while the electrical conductivity reached up to 4 $\mathrm{dS} / \mathrm{m}$ at the end the experiment for the three irrigation intervals, with the highest salinity level at the treatments irrigated every day and every second days mainly under $7 \mathrm{dS} / \mathrm{m}$ saline irrigation level (Figure 5). The low irrigation intervals imposed a more rapid salt accumulation in the root zone, which was ascribed to restriction of the volume of drainage solution.

[26-28] reported that one consequence of reducing irrigation water use by deficit irrigation is the greater risk of increased soil salinity due to reduced leaching. The soil $\mathrm{pH}$ was in the normal range and was not affected by the saline irrigation during the growing period (Figure 6).

\section{Conclusions}

Evidence from this study indicated that, under moderate
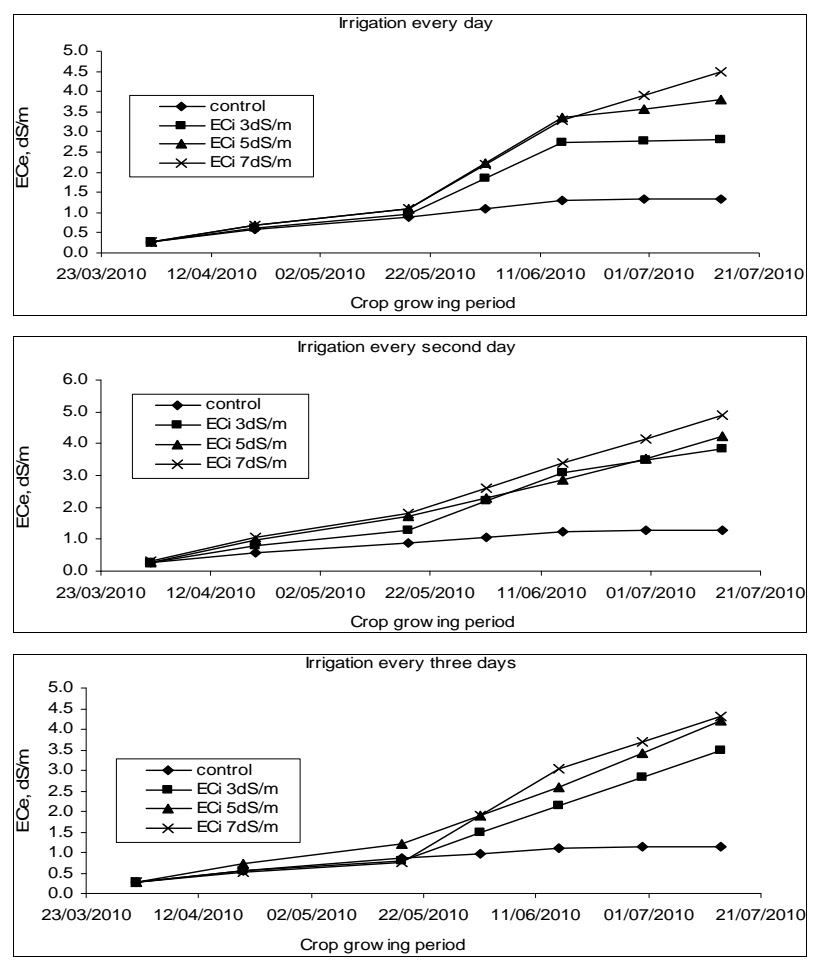

Figure 5. Impact of saline water irrigation through three irrigation intervals on soil electrical conductivity during the growing period at depth of $0-30 \mathrm{~cm}$.
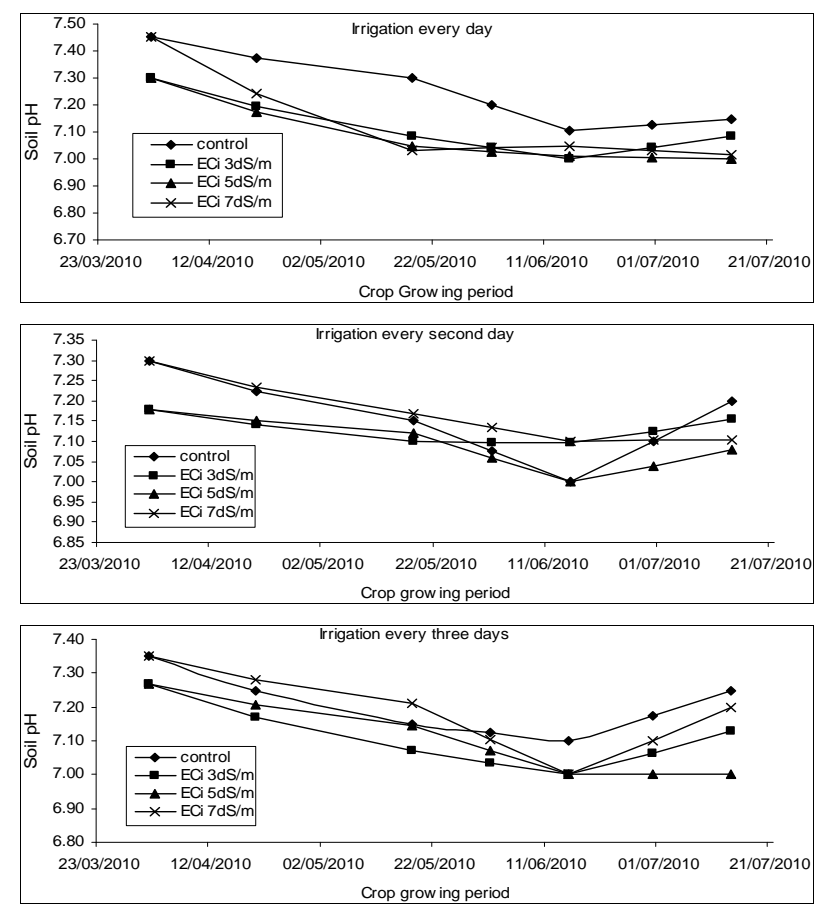

Figure 6. Impact of saline water irrigation through three irrigation intervals on soil $\mathrm{pH}$ during the growing period at depth of $0-30 \mathrm{~cm}$.

saline irrigation $(3 \mathrm{dS} / \mathrm{m})$ the tomato yield production was not significantly affected by irrigation intervals, while under highly saline irrigation $(5,7 \mathrm{dS} / \mathrm{m})$, the yield production significantly affected by irrigation intervals. Accordingly, when highly saline water is used for irrigation, it is recommended to use short irrigation interval (one day interval) instead of applying irrigation every three or four day as it is practiced by the farmers. However, the short irrigation interval practice normally reduces the plant stress under saline irrigation.

Regarding the salt accumulation in the root zone, the results of this study showed an increase in soil salinity that reached up to $4 \mathrm{dS} / \mathrm{m}$ at the end of the growing period, particularly under highly saline irrigation. This emphasizes the need for conservation of soil properties besides the yield production of tomato under long-term saline irrigation.

\section{REFERENCES}

[1] A. Lauchli and E. Epstein, "Plant Responses to Saline and Sodic Conditions," In: K. K. Tanji, Ed., Agricultural Salinity Assessment and Management. Manuals and Reports on Engineering Practice, ASCE, New York, 1990, pp. 113-137.

[2] R. Munns, "Physiological Processes Limiting Plant Growth in Saline Soil: Some Dogmas and Hypotheses," Plant, Cell \& Environment, Vol. 16, No. 1, 1993, pp. 15-24. doi:10.1111/j.1365-3040.1993.tb00840.x

[3] D. Pasternak and Y. De Malach, "Crop Irrigation with 
Saline Water," In: M. Pessarakli, Ed., Handbook of Plant and Crop Stress, Marcel Dekker, Inc., New York, 1995, pp. 599-622.

[4] M. Shannon and C. Grieve, "Tolerance of Vegetable Crops to Salinity," Horticulture Science, Vol. 78, No. 1-4, 1999 , pp. 5-38.

doi:10.1016/S0304-4238(98)00189-7

[5] A. Bustan, M. Sagi, Y. De Malach and D. Pasternak, "Effects of Saline Irrigation Water and Heat Waves on Potato Production in an Arid Environment," Field Crops Research, Vol. 90, No. 2-3, 2004, pp. 275-285.

doi:10.1016/j.fcr.2004.03.007

[6] N. Malsh, T. Flowers and R. Ragab, "Effect of Irrigation Systems and Water Management Practices Using Saline and Non-Saline Water on Tomato Production," Agricultural Water Management, Vol. 78, No. 1-2, 2005, pp. 2538.

[7] S. Jalota, A. Sood, G. Chahal and B. Choudhury, "Crop Water Productivity of Cotton," Agricultural Water Management, Vol. 84, No. 1-2, 2006, pp. 137-146. doi:10.1016/j.agwat.2006.02.003

[8] M. Ali, M. Hoque, A. Hassan and M. Khair, "Effect of Deficit Irrigation on Yield, Water Productivity and Economic Returns of Wheat," Agricultural Water Management, Vol. 92, No. 3, 2007, pp. 151-161.

[9] K. Nagaz, I. Toumi, M. Masmoudi and N. Ben Mechlia, "Soil Salinity and Barley Production under Full and Deficit with Saline Water in Arid Conditions of Southern Tunisia," Research Journal of Agronomy, Vol. 2, No. 3, 2008, pp. 90-95.

[10] U. Shani and L. Dudley, "Field Studies of Crop Response to Water and Salt Stress," Soil Science Journal, Vol. 65, No. 5, 2001, pp. 1522-1528. doi:10.2136/sssaj2001.6551522x

[11] O. Gideon, Y. DeMalach, L. Gillerman, I. David and S. Lurie, "Effect of Water Salinity and Irrigation Technology on Yield and Quality of Pears," Biosystem Engineering, Vol. 81, No. 2, 2002, pp. 237-247.

[12] N. Katerji, J. van Hoorn, A. Hamdy and M. Mastrorilli, "Comparison of Corn Yield Response to Plant Water Stress Caused by Salinity and by Drought," Agricultural Water Management, Vol. 65, No. 2, 2004, pp. 95-101.

[13] R. Munns, "Comparative Physiology of Salt and Water Stress," Plant, Cell \& Environment, Vol. 25, No. 2, 2002, pp. 239-250.

[14] G. Hammer and I. Broad, "Genotype and Environment Effects on Dynamics of Harvest Index during Grain Filling Sorghum," Agronomy Journal, Vol. 95, No. 1, 2003, pp. 199-206. doi:10.2134/agronj2003.0199

[15] L. Feitosa, J. Cambraia, M. Oliva and H. Ruiz, "Changes in Growth and in Solute Concentration in Sorghum Leaves and Roots during Salt Stress Recovery," Environmental and Experimental Botany, Vol. 54, No. 1, 2005, pp. 69-76.

[16] C. Sonneveld and G. Welles, "Yield and Quality of
Rockwool-Grown Tomatoes as Affected by Variations in EC-Value and Climatic Conditions," Plant Soil, Vol. 111, No. 1, 1988, pp. 37-42.

[17] Y. Li, C. Stanghellini and H. Challa, "Effect of Electrical Conductivity and Transpiration on Production of Greenhouse Tomato (Lycopersicon esculentum L.)," Horticulture Science, Vol. 88, No. 1, 2001, pp. 11-29. doi:10.1016/S0304-4238(00)00190-4

[18] R. Eltez, Y. Tuzel, A. Gul, I. Tuzel and H. Duyar, "Effect of Different EC Levels of Nutrient Solution on Greenhouse Tomato Growing," Acta Horticulture, Vol. 573, 2002, pp. 443-448.

[19] P. Adams and L. Ho, "Effect of Constant and Fluctuating Salinity on the Yield, Quality and Calcium Status of Tomatoes," Journal of Horticulture Science, Vol. 64, No. 6, 1989, pp. 725-732.

[20] W. Van Ieperen, "Effect of Different Day and Night Salinity Levels on Vegetative Growth, Yield and Quality of Tomato," Journal of Horticulture Science, Vol. 71, 1996, pp. 99-111.

[21] J. Magan, M. Gallardo, R. Thompson and P. Lorenzo, "Effect of Salinity on Fruit Yield and Quality of Tomato Grown in Soil-Less Culture in Greenhouse in Mediterranean Climatic Conditions," Agricultural Water Management, Vol. 95, No. 9, 2008, pp. 1041-1055.

[22] E. Maas and G. Hoffman, "Crop Salt Tolerance: Current Assessment," Journal of Irrigation, Vol. 103, No. 2, 1977, pp. 115-134.

[23] T. Soria and J. Cuartero, "Tomato Fruit Yield and Water Consumption with Saline Water Irrigation," Acta Horticulture, Vol. 458, 1997, pp. 215-219.

[24] R. Romero-Aranda, T. Soria and J. Cuartero, Tomato "Plant Water-Uptake and Plant-Water Relationships under Saline Growth Conditions," Plant Science, Vol. 160, No. 2, 2000, pp. 265-272. doi:10.1016/S0168-9452(00)00388-5

[25] B. Ould Ahmed, M. Inoue and S. Moritani, "Effect of Saline Water Irrigation and Manure Application," Agricultural Water Management, Vol. 97, No. 1, 2010, pp. 165-170.

[26] G. Schoups, J. Hopman, C. Young, J. Vrugt, W. Wallender, K. Tanji and S. Pandy, "Sustainability of Irrigated Agriculture in the San Joaquin Valley," Proceedings of the National Academy of Sciences of the United States of America, Vol. 102, No. 43, 2005, pp. 15352-15356.

[27] H. Kaman, C. Kirda, M. Cetin and S. Topcu, "Salt AccuMulation in the Root Zone of Tomato and Cotton Irrigated with Partial Root-Drying Technique," Irrigation and Drainage, Vol. 55, No. 5, 2006, pp. 533-544.

[28] S. Geerts, D. Raes, M. Garcia, O. Condori, J. Mamani, R. Miranda, J. Cusicanqui, C. Taboada and J. Vacher, "Could Deficit Irrigation Be a Sustainable Practice for Quinoa (Chenopodium quinoa Willd.) in the Southern Bolivian Altiplano," Agricultural Water Management, Vol. 95, No. 8, 2008, pp. 909-917. 